\title{
The Implementation of Vocabulary Teaching at SDN Cemara Dua Surakarta
}

\author{
Ni Made Dita Ningrum, Joko Nurkamto, Ngadiso
}

\author{
English Education Department \\ Teacher Training and Education Faculty \\ Sebelas Maret University of Surakarta
}

Email: nimadeditaningrum@ymail.com

\begin{abstract}
This article describes the implementation of vocabulary teaching at SDN in Surakarta The objectives of this research are (1) to describe the implementation of vocabulary teaching at the first grade, (2) to find out the problems of vocabulary teaching at the first grade, and (3) to find out the solutions of vocabulary teaching. The method used in this research was descriptive method. The data were collected through observation, interview and document analysis. The data were analyzed using interactive model of analysis including reducing the data, presenting the data and drawing conclusion. The result of the research shows that (1) the implementation of vocabulary teaching consists of four dimensions. They are background, aims, kind and process of teaching vocabulary, (2) in teaching vocabulary, there are problems faced by the teacher and the students, and (3) there are the solutions for the problems.
\end{abstract}

Keywords: vocabulary, teaching vocabulary

\section{INTRODUCTION}

Vocabulary is one of the language elements that should be learnt at primary level. It is the first thing that the students of Elementary School should learn well. It is a very important part in learning language and it is basic matter in teaching and learning. In learning vocabulary, if students have bad vocabulary, it will cause problems in understanding the learning material and the explanation given by teacher. It isstated by

Rivers in Nunan (1991: 117), "the acquisition of an adequate vocabulary is essential for successful second language use because without an extensive vocabulary, we will be unable to use the structures and functions we may have learned for comprehensible communication". In other words, the students need to learn what words mean and how they are used.

Vocabulary plays an important role in learning a foreign language. In learning English, it is an element that links the four skills of (1) listening, (2) reading, (3) speaking, and (4) writing together. Before acquiring four language skills, it is important to understand vocabulary first. Students often face difficulties in learning English because the lack of vocabulary. Finally, the difficulties bring effect to other language skills. Therefore, the teacher has an important role to help and motivate his or her students to master vocabulary.

Zhang in Reid (1994:229) states that it is very difficult to express an idea in the form of writing if one has inadequate vocabulary.Meanwhile, Aebersold and Field (1997:138) state that knowing vocabulary is important for getting meaning from a text, for example in reading comprehension. According to them, understanding the basics of grammatical structure enables readers to understand the relationship between words, but it does not provide access to the meaning of the sentence.

Vocabulary plays an important role not only in writing and reading, but also in speaking and listening. Allen (1998: 3) states that students who do not learn grammar along with vocabulary will not be able to use the 
language for communication. It means that although the students master grammar well, they will find difficulties to communicate if they have inadequate vocabulary. While listening, if the students have inadequate vocabulary, they will lack of information from the source data because what they heard is wrong. It can make misunderstanding of the information.

English is taught formally in Elementary school. But,most students of Elementary School still have difficulties in learning vocabulary. Generally, there are problems faced by students in learning vocabulary. The problems are (1) students have difficulty to remember the vocabulary. They have difficulty in remembering the meaning of vocabularies. (2) Students have difficulty in writing the vocabularies. They often write the some words as they heard. (3) Students tend to pronounce the words in Indonesian pronunciation. Some of them think pronouncing English words are the same with Indonesian words. (4) Students have difficulty to use the vocabulary. They have difficulty in making a sentence because they still have a little bit knowledge about grammar.

In reality, teaching vocabulary to children is not easy. Basically, children like playing and doing something while learning. Children take great pleasure in finding and creating fun in what they do. Therefore, there are many problems that will be faced by the teacher, when he or she introduces English words to his or her students. For the students, English is something new and different from their mother tongue. Based on the phenomenon, the role of the teacher is needed to help his or her students learn vocabulary effectively even improving their vocabulary mastery. Teacher should find an appropriate technique to make them learn.

From the explanation above, the research questions can be formulated:

1. What is the implementation of vocabulary teaching at the first grade students ?

a. Background of vocabulary teaching at the first grade? b. Aim of vocabulary teaching at the first grade students in SDN Cemara Dua?

c. Kinds of vocabulary taught by the teacher at the first grade?

d. Process of vocabulary teaching at the first grade?

2. What are the problems in teaching vocabulary at the first grade?

3. What are the solutions for the problems in teaching vocabulary at the first grade?

This research has three objectives of the study, they are:

1. To describe the implementation of vocabulary teaching at the first grade.

2. To find out the problems of vocabulary teaching at the first grade.

3. To find out the solutions of vocabulary teaching at the first grade.

\section{RESEARCH METHODS}

In conducting this research, the researcher used descriptive method. This research belongs to the descriptive method because this research aims at describing systematically about the facts on the surrounding environment the researcher has got.The data obtained in this research are in the form of words; therefore, this research belongs to qualitative research.

The research data in this study was collected in the form of information about the implementation of vocabulary teaching. The sources of data used in this study were events, informants and documents. The events were the process of teaching vocabulary in the classroom. The informants were the English teacher and the students. The documents used in this research were lesson plan, handout book, slides, student"s worksheet, and field note. The researcher also employed videos and photograph as documentation.

In this study, the techniques of collecting data used were observation, interview and document. The researcher used naturalistic observation carried in an English classroom. After did the observation, the 
researcher interviewed the English teacherabout teaching vocabulary. Besides, the researcher interviewed two students. The documents analyzed in this research were lesson plan, handout book, slides, student"s worksheet, and field note, and photographs of the implementation of teaching vocabulary.

After the data were collected, the data was analyzed to get the conclusion. The data in this research were analyzed by using descriptive qualitative method. The researcher used an interactive model of analysis that includes three main components, namely reducing the data, presenting the data and drawingconclusion. After the researcher collected the data, she reduced and presented the data. In reducing the data, the researcher rejected meaningless data, so she got the important points of finding. It was followed by presenting the data; it means that the researcher presented the data systematically and logically, so the meaning of every event is clear. In the end of collecting the data, the researcher tried to verify the data based on reducing and presenting the data.

\section{RESEARCH FINDINGS AND DISCUSSION}

The research finding discovered some important points as follows: (1)the implementation of vocabulary teaching at the first grade; (2) the problems of vocabulary teaching at the first grade; and (3) the solutions for the problems of vocabulary teaching at the first grade. The brief explanation is as follows:

1. In the implementation of vocabulary teaching at the first grade students, it consists of four dimensions. They are (a) background; (b) aim; (c) kinds; and (d) process of teaching vocabulary.

a. Background of teaching vocabulary at the first grade

Vocabulary is one of the important language elements in teaching English. It is the first thing that the students of Elementary School should learn well because if students have bad vocabulary, it will cause problems in understanding the learning material and the explanation given by teacher.

Coady and Huckin (1997: 5) state that vocabulary is central to language and of critical importance to the typical language learner. It means that the student will find difficulties in learning English if they do not learn about vocabulary before. The teacher said that "vocabulary sangat penting mbak, perlu diajarkan dari level rendah karena apabila siswa tidak dapat menguasai dengan baik akan kesulitan dalam memahami dan menerima pelajaran."

b. Aim of teaching vocabulary teaching vocabulary at the first grade

Aim of teaching vocabulary is to prepare students at the next level. As stated by the teacher on the interview " pengajaran vocabulary sangat penting mbak di kelas satu karena untuk mempersiapkan di kelas selanjutnya. Kalau di kelas satu pengajaran vocabulary tidak benar akan mempengaruhi di kelas selanjutnya." The teacher added that “ pengajaran vocabulary juga bertujuan mbak agar siswa dapat berlatih berkomunikasi dengan temannya,

kalau penguasaan vocabularyny bagus komunikasinya juga lancar." Allen (1998: 3) states that students who do not learn grammar along with vocabulary will not be able to use the language for communication. It means that although the students master grammar well, they will find difficulties to communicate if they have inadequate vocabulary.

c. Kind of vocabulary taught by the teacher at the first grade

There were some themes taught at the first grade students. They were days, numbers, colour, animals, thing in bag,etc. When the writer did the observation, the teacher 
taught about "things in our bag". The vocabularies were a pencil, book, sharpener, coloring pencil, eraser etc. The teacher also taught about number. She asked the students to count the number of pencil, book, sharpener, etc. It was still related to the theme things our bag. Kind of vocabulary taught by the teacher is receptive vocabulary. Haycraft in Hatch and Brown (1995: 370) states that receptive vocabulary is words that the student recognizes and understands, when they occur in a context, but which he cannot produce correctly. She introduced vocabulary first and then asked the students to recognize and understand them in the activities.

d. Process of vocabulary teaching at the first grade in SDN Cemara Dua.

In the process of vocabulary teaching, the teacher used three steps.The first was opening. The teacher gave greetings, asked the students to pray, checked the students attandence,stated the topic of the lesson. She also reviewed the last material given before moving to the new topic. She wanted to make sure that the students have already understood the material. It was a good activity because the students recall their knowledge about the last material given. It also helped the teacher to check the students ${ }^{\text {ee }}$ readiness to receive the new material.

The second was main activity. In this step, the teacher should provide activites that are appropriate to students ${ }^{\text {ee }}$ needs and interests. It will influence the success of teachinglearning process. As stated by Richards and Rogers (2001: 210), the students learn best when instruction addresses students ${ }^{\text {ee }}$ needs. In this step, the teacher divided into four sections which were presentation, production, practice, and test. In main activity, the activities were related to vocabulary. As stated by Cross (1995: 11), the prodecure of teaching vocabulary can be divided into three stages which are presentation, production, and practice.

In giving presentation, she applied some techniques. The techniques matched with the topic of the lesson and the students ${ }^{\text {ee }}$ interest.

They were real things/realia, repetition, and picture.

In giving practicing, the teacher integrated vocabulary with language skills. They were listening, reading, speaking, and writing. Each skil had some practices. The English teacher integrates vocabulary with four language skills well. She taught vocabulary implicitly. According to Hornby (2000: 680) implicit is suggested with out being directly expressed. Vocabulary does not teach separetly from language skills.

Third was closing. Before ending the class, the teacher gave a homework. It was a good idea because the students would learn the material given by the teacher anymore at home. It could make them to memorize the material well. The teacher also asked the students to sing together.

In teaching vocabulary, the teacher was not the one who presented the material but the students were also demanded to be active in the class. The teacher tried to make the students active in learning vocabulary by guiding them to ask, answer, and develop their comprehending to the material being taught, so the teacher wanted to place herself as a facilitator. It is supported by Brown (2000: 160) that one teacher"es role is as a facilitator.

2. The Problems of Vocabulary Teaching at the First Grade 
In teaching vocabulary, there were some problems faced by the teacher and the students. The problems of the teacher were big class and lack of facilities. Big class was one of the problems of teaching vocabulary. When the teacher explained the material in front of the class, there were some students who were busy with their own activities. They spoke with their friends or doing other things. As stated by Scott and Yterberg (1990:2) young learners have a very short attention and concentration span.They could not focus on material explained by their teacher. Finally, they could not accept the material well. It influenced the teaching and learning process.The facilities of teaching vocabulary were not complete. It could be seen from the facilities of the class. There were not pictures or things related to vocabulary such as name of fruits, name of alphabets, name of body parts, etc so that the students could not enrich their vocabulary. The English teacher provided her own media based on the topic.

The problems of the students are difficulties to memorize, pronounce, and write English words. In memorizing, the students often have difficulty to remember the English words.It normally happens because their daily language is Indonesia. Watts in Freeman and Richard (1996: 24) states that the average child enters elementary school should be able to recognize vocabulary of 2000 words.

In pronuncing, the students made many mistakes. They often read them alphabetically just same as they did in reading Indonesian words. It will cause misunderstanding of communication. Actually, children imitate words easily. As stated by Brewster (2002: 85) children are generally good at imitating and will pick up the model of pronunciation more easily than adults. In writing, the students often made mistake. They thought that the spelling and pronunciation were the same.
In fact, English and Indonesia are very different.

3. The Solutions for the Problems of Vocabulary Teaching at the First Grade In solving the problems, the teacher and the students have some solutions. For the solution for the big class, the teacher uses some tricks. The first trick, the teacher asks the students to be silent. The second, she asks them to sing together. Griffee (1992:4) states that songs relax students in the classroom and provide an enjoyable classroom atmosphere. They will not be bored. And the last is to give a score in each group of the students by giving some questions.

For the solutions for lack facilities, the teacher takes the references from the internet, such as videos and pictures. Brewster (2002: 90) states that visual support helps students understand the meaning and helps to the word memorable.

The students have some solutions in solving the problems, In memorizing English words, the students memorize again the vocabulary at home. They also have a private teacher to support their learning.As stated by Johnson and Swain (1997: 197),parents who do not themselves speak English often employ tutors to provide their children with private tuition in the home or enroll their children in courses such as speech and drama, or other language related courses.

In pronouncing English words, the students ask the teacher to repeat them for several times. They also consult with their friends by making a small group discussion. Kidsvatter (1996: 242) says that small group seems to provide an opportunity for students to become more actively engaged. They also learn with a private teacher. In writing English words, the students practice writing them for many times until they could write them well. They also consult with their teacher. 


\section{CONCLUSION, IMPLICATION AND SUGGESTION}

Based on the research findings presented above, it can be concluded that The implementation of vocabulary teaching consists of four dimensions. They are background, aims, kind and process of teaching vocabulary. There are problems of vocabulary teaching. The problems are not only faced by the teacher but also the students. The problems of the teacher are big class and lack of facilities. The problems of the students are difficulties to memorize, pronounce, and write English words.

In solving the problems, the teacher and the students have some solutions. For the solution for the big class, the teacher uses some tricks. The first trick, the teacher asks the students to be silent. The second, she asksthem to sing together and the last is to give a score in each group of the students by giving some questions. For the solutions for lack facilities, the teacher takes the references from the internet.

The students have some solutions in solving the problems, In memorizing English words, the students memorize again the vocabulary at home. They also have a private teacher to support their learning. In pronouncing English words, the students ask the teacher to repeat them for several times. They also consult with their friends by making a small group discussion. They also learn with a private teacher. In writing English words, the students practice writing them for many times until they could write them well. They also consult with their teacher.

This study has implications which is the teacher teaches aspects of vocabulary. It can be seen from the activities in the classroom. In speaking activity, she drills the students how to pronounce vocabulary well. She asks them to repeat vocabularies after her.It means that she teaches pronounciation aspect.The objective is to make the students know what a word sound like.
The teacher also teaches how to spell vocabulary such as a book, pen, pencil, bag, etc. She wrote them on the whiteboard. It means that she teaches spelling aspect so that the students know what does it look like. When teaching vocabulary, the teacher also teaches meaning. She will teach meaning, if the students have difficulty to understand vocabulary.

Having concluded the result of the research, the researcher would like to propose some sugesstions for the school itself. The schoolshould make each class only 25 students or not more than 30 students. It will make the teacher easily control the students and create a conducive class situation so that the students can learn maximally. Besides, the school has to completethe facilities to support the development of teaching and learning process. The school can also provide some activities like teacher training that can improve the quality of the teacher in teaching English.

For English teachers, they should learn the characteristics of the students in order to know exactly what they need and what problems they face on learning vocabulary. By learning it, the English teacher could select the appropriate technique in teaching vocabulary for children. English teacher also should encourage the students to be active and creative by providing many activities. The teacher can use interesting aids and methods so that they can be interested in English lesson.

For students, they should pay attention to the teacher when the teacher explains lesson.They should also learn English intensively and continuously to improve their English skill. They must also motivate themselves to be active students so that they will understand the material easily.

For the other researchers, the writer hopes that the result of this study will be useful for the other researchers as the consideration to do the other research especially about the process of teaching vocabulary at the first grade students of elementary school. 


\section{BIBILIOGRAPHY}

Aebersold, J. And Field M. 1997. From Reader to Reading Teacher. Cambridge:

Cambridge University Press

Allen, F. Virginia. 1998. Technique in

Teaching Vocabulary. Oxford: Oxford University Press

Brewster, Jean (et.al). 2002. The Primary English Teacher"s Guide. England: Longman

Brown, H. Douglas. 2000. Principles of Language Learning and Teaching. New Jersey: Prentice Hall

Coady, James and Thomas Huckin. 1997. Second Language Vocabulary Acquisition. Cambridge: University Press

Cross, David. 1995. A Practical Handbook of Language Teaching. Cassel

Freeman, Donald and Jack Richards. 1996.

Teacher Learning in Language Teaching. Cambridge: University Press

Griffe. Dale. 1992. Songs in Action. Cambridge : University Press
Hatch, Evelyn and Brown, Cheryl. 1995.

Vocabulary, Semantics, and

Education. USA. Cambridge

University Press

Hornby. 2000. Advance Learner"s Dictionary. New York: Oxford University Press

Johnson, R.K., Swain, M. 1997. Immersion

Education:

International

Perspectives. Cambridge: Cambridge University Press

Kidsvater, Richard. 1996. Dynamics of Effective Teaching. London: Longman Published Ltd

Nunan, David. 1991. Language Teaching Methodology. London: Prentice Hall

Richards, J. C. and W. A. Renandya.2002.Methodology inLanguage Teaching: An Anthology of CurrentPractice. Cambridge: Cambridge University Press

Scott, Wendy Aand Libeth H. Yterberg.1998.

Teaching English to Children. Harlow: Longman 